We are grateful to Miss Ruth Wood for her help in the preparation and typing of this paper.

1 Hundel JM, Diehl WK, Diggs ES. Hormone influences upon the ureter. $A m \mathcal{f}$

2 Trant HF, McLane CM. Physiological changes in the ureter associated with pregnancy. Surg Gynecol

(Accepted 18 fanuary 1985)

Wordsley Hospital, Stourbridge, West Midlands DY8 5QX

G J LEWIS, MB, MRCOG, consultant in obstetrics and gynaecology $S$ P CHATTERJEE, MB, BS, registrar in obstetrics and gynaecology A D ROWSE, MSC, FRCS, consultant urologist

\section{Captopril and domiciliary oxygen in chronic airflow obstruction}

Inhibition of angiotensin converting enzyme has been reported to reduce pulmonary arterial pressure in primary pulmonary hypertension $^{1}$ and to reduce total pulmonary resistance and increase cardiac output in some patients with pulmonary hypertension secondary to collagen vascular disease. ${ }^{2} \mathrm{We}$ therefore investigated the effects of captopril (3-mercapto-2-methylpropionyl-proline), a potent and relatively specific angiotensin converting enzyme inhibitor, in five patients with pulmonary hypertension secondary to hypoxic chronic airflow obstruction.

\section{Patients, methods, and results}

The study group comprised five patients with chronic airflow obstruction (mean forced expiratory volume in one second $\left(\mathrm{FEV}_{1}\right) 0.711$; mean forced vital capacity (FVC) 1.361 ; mean $\mathrm{FEV}_{1} / \mathrm{FVC} 52 \%$ ) and resting arterial hypoxaemia (mean arterial oxygen pressure $\left(\mathrm{PaO}_{2}\right) 6.8 \mathrm{kPa}(51 \mathrm{~mm} \mathrm{Hg})$ breathing room air) who took domiciliary oxygen with proved good compliance for at least four months before the study (mean daily oxygen use $19 \cdot 4$ hours, assessed by a concealed meter attached to the oxygen concentrator machines)

Baseline measurements (see table) were made, and after an initial test dose of $12.5 \mathrm{mg}$, which was well tolerated, captopril was given in a dose of 25 mg thrice daily for three days. All measurements were repeated frequently during this period. Statistical analysis of the results at baseline and after three days of captopril was carried out by paired Student's $t$ test.

Cardiac output was measured in triplicate using the thermodilution method (Edwards $9520 \mathrm{~A}$ cardiac output computer) and mean values recorded. Haemodynamic measurements were calculated by computer (Cardiac Recorders Ltd, Memory Monitor 3220) from pressure transducers (Bell and Howell type 4-327-1). All measurements, including blood gas analysis, were made after the patients had breathed room air for at least 30 minutes.

Baseline results (table) showed increased pulmonary vascular resistance and pulmonary arterial pressure, appreciable arterial hypoxaemia and mild hypercapnia, and a greatly increased alveolar-arterial oxygen gradient $(\mathrm{A}-\mathrm{aDo})_{2}$ ).

After three days of captopril both pulmonary arterial pressure and pulmon- ary vascular resistance were significantly reduced $(p<0.05)$ and cardiac output significantly increased $(\mathrm{p}<0.01)$. Although systemic blood pressure and systemic vascular resistance were reduced $(p<0.01)$, no patient developed symptoms related to inadequate perfusion. Both oxygen delivery to the tissues and mixed venous $\mathrm{PO}_{2}\left(\mathrm{P}_{\mathrm{v}} \mathrm{O}_{2}\right)$ were significantly increased $(\mathrm{p}<0.01)$, reflecting the increased cardiac output, although the rise in $\mathrm{A}-\mathrm{aDo}_{2}$ at the end of the study $(\mathrm{p}<0.05)$ suggested that hypoxic pulmonary vasoconstriction was impaired by the drug.

\section{Comment}

Although the presence of pulmonary hypertension is associated with a poor prognosis in chronic airflow obstruction, ${ }^{3}$ a reduction in pulmonary arterial pressure alone may not be therapeutic unless tissue oxygenation is also improved. ${ }^{4}$ In our patients the reduction in pulmonary arterial pressure achieved with captopril was accompanied by significantly increased $\mathrm{P}_{\bar{v}}{ }_{2}$ values and it therefore seems reasonable to suggest that in addition to its haemodynamic effects, tissue oxygenation was also increased by the drug.

Since three days' treatment with captopril had a beneficial effect on factors known to be associated with a poor prognosis in chronic airflow obstruction, and similar results have been reported with other vasodilators, further studies seem indicated in the context of a controlled clinical trial (with and without domiciliary oxygen) to assess the long term risks and benefits of vasodilator drugs in chronic airflow obstruction.

We thank the ward sister and nursing staff of the coronary care unit, St Laurence's Hospital, for their help with this study.

1 Ikram H, Maslowski AH, Nicholls MG, Espiner EA, Hull FTN. Haemodynamic and hormonal effects of captopril in primary pulmonary hypertension. Br Heart $f$

2 Niarchos AP, Whitman HH, Goldstein JE, Laragh JH. Hemodynamic effects of captopril in pulmonary hypertension of collagen vascular disease. Am Heart $\mathcal{F}$

3 Renzetti AD Jr, McClement JH, Litt BD. Veterans Administration cooperative study of pulmonary function: III. Mortality in relation to respiratory function in chronic obstructive pulmonary disease. Am $\mathcal{F}$ Med 1966;41:115-29.

4 Bergofsky EH. Tissue oxygen delivery and cor pulmonale in chronic obstructive pulmonary disease. $N$ Engl $₹$ Med 1983;308:1092-4.

5 Kawakami Y, Kishi F, Yamamoto $\mathrm{H}$, Miyamoto $\mathrm{K}$. Relation of oxygen delivery, mixed venous oxygenation, and pulmonary hemodynamics to prognosis in .

(Accepted 10 fanuary 1985)

St Laurence's Hospital, Dublin 7, Ireland

CONOR M BURKE, MRCPI, MRCP, medical registrar

MARIE HARTE, MRCPI, consultant cardiologist

JACQUELINE DUNCAN, MB, medical senior house officer

HEIDI M CONNOLLY, medical student

JOHN H HORGAN, FRCPI, FCCP, consultant cardiologist

Stanford University School of Medicine, Stanford, California, USA JAMES THEODORE, MD, associate professor of medicine

James Connolly Memorial Hospital, Blanchardstown, Dublin

BRENDAN CALLAGHAN, director, department of respiratory medicine

Correspondence to: Dr Conor M Burke, Postdoctoral Fellow, Division of Respiratory Medicine, Stanford University Medical Center, Stanford, California 94305, USA.

\begin{tabular}{|c|c|c|c|c|c|}
\hline \multirow[b]{2}{*}{ Measurement } & \multicolumn{2}{|c|}{ Baseline } & \multicolumn{2}{|c|}{ Captopril } & \multirow[b]{2}{*}{ p Value } \\
\hline & Mean & SD & Mean & SD & \\
\hline 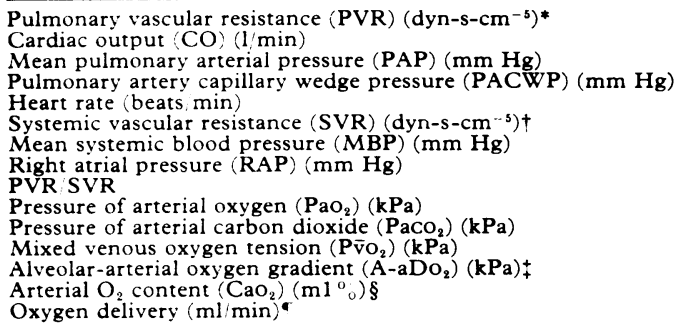 & $\begin{array}{c}470 \cdot 4 \\
4 \cdot 62 \\
33 \cdot 8 \\
8 \cdot 8 \\
93 \cdot 2 \\
1552 \cdot 0 \\
94 \cdot 0 \\
6 \cdot 8 \\
0.30 \\
6 \cdot 8 \\
5.8 \\
3 \cdot 8 \\
5 \cdot 6 \\
17 \cdot 0 \\
793 \cdot 4\end{array}$ & $\begin{array}{c}216 \cdot 0 \\
1.05 \\
7 \cdot 3 \\
1.3 \\
19 \cdot 3 \\
316 \cdot 4 \\
11.3 \\
4 \cdot 1 \\
0.13 \\
0.9 \\
1.1 \\
0.7 \\
1.4 \\
1.9 \\
235 \cdot 8\end{array}$ & $\begin{array}{c}274 \cdot 8 \\
5 \cdot 66 \\
26.0 \\
7 \cdot 6 \\
101 \cdot 6 \\
1075 \cdot 8 \\
78 \cdot 0 \\
3 \cdot 6 \\
0.26 \\
6 \cdot 6 \\
5 \cdot 6 \\
4 \cdot 1 \\
6 \cdot 4 \\
16 \cdot 8 \\
962 \cdot 0\end{array}$ & $\begin{array}{c}129.4 \\
1.01 \\
8 \cdot 1 \\
2 \cdot 1 \\
24 \cdot 0 \\
211.9 \\
9 \cdot 2 \\
2.6 \\
0 \cdot 14 \\
0.9 \\
1 \cdot 1 \\
0.6 \\
1.2 \\
1.7 \\
269.9\end{array}$ & $\begin{aligned}<0.05 \\
<0.01 \\
<0.05 \\
\text { NS } \\
\text { NS } \\
<0.01 \\
<0.001 \\
<0.05 \\
\text { NS } \\
\text { NS } \\
<0.05 \\
<0.01 \\
<0.05 \\
\text { NS } \\
<0.01\end{aligned}$ \\
\hline
\end{tabular}

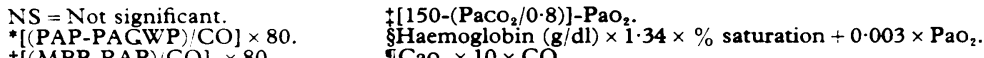

Conversion: SI to traditional units- $\mathrm{PaO}_{2}, \mathrm{PaCO}_{2}, \mathrm{P}_{\overline{\mathrm{v}}}, \mathrm{A}-\mathrm{aDo},: 1 \mathrm{kPa} \approx 7.5 \mathrm{~mm} \mathrm{Hg}$. 